ISSN : 2549-0532 (Cetak)

\title{
KARAKTERISTIK BALITA PENDERITA PNEUMONIA BERDASARKAN FAKTOR RISIKO DI RSUD ABDUL WAHAB SJAHRANIE SAMARINDA TAHUN 2018
}

\author{
Nurul Fatimah ${ }^{1}$, Sukartini ${ }^{2}$, Nataniel Tandirogang ${ }^{3}$ \\ ${ }^{1}$ Program Studi Kedokteran, Fakultas Kedokteran Universitas Mulawarman \\ ${ }^{2}$ Laboratorium Ilmu Kesehatan Anak, Fakultas Kedokteran Universitas Mulawarman \\ ${ }^{3}$ Laboratorium Mikrobiologi, Fakultas Kedokteran Universitas Mulawarman \\ email :nr.fatimah76@gmail.com,dr.sukartini@yahoo.com,nataniel@idikaltim.org
}
Dikirim
: 12 Desember 2019
Diterima
: 30 Januari 2019
Diterbitkan
: 20 Maret 2020

Pneumonia is an acute respiratory infection that affects the lung parenchyma, which is still the leading cause of children under-five mortality throughout the world. Age 1-24 months, low birth weight, and undernourished are the risk factors for pneumonia. The purpose of this study was to determine the description of the characteristics of children under-five patients with pneumonia in Abdul Wahab Sjahranie Hospital Samarinda, based on the risk factors. This research is a descriptive observational study. The samples of this study were all the pneumonia children underfive patients who were hospitalized at Abdul Wahab Sjahranie Hospital in JanuaryDecember 2018, according to the characteristics of the sample set by the researchers, which were taken by purposive sampling technique. The data used were secondary data obtained from patient medical records, taken in June 2019 at the Medical Record Installation, Abdul Wahab Sjahranie Hospital. The number of samples obtained was 42 pneumonia patients. More children suffering from pneumonia were found in age 1-24 months (78.6\%), normal birth weight (61.9\%), and undernourished (57.1\%)

Keywords: Pneumonia, risk factors, children under-five 


\section{PENDAHULUAN}

Pneumonia adalah penyakit infeksi saluran pernapasan akut yang menginfeksi parenkim paru. Ketika seseorang menderita pneumonia, alveoli terisi dengan nanah dan cairan, sehingga menimbulkan nyeri ketika bernapas, dan asupan oksigen menurun (WHO, 2019). Pneumonia sebagian besar disebabkan oleh mikroorganisme (virus, bakteri, jamur, parasit), dan sebagian kecil disebabkan oleh aspirasi maupun radiasi (Said, 2015).

Saat ini, pneumonia masih menjadi penyakit infeksi utama yang menyebabkan kematian pada balita di dunia. Pada tahun 2018, pneumonia membunuh lebih banyak balita dibandingkan dengan penyakit menular lainnya, dengan merenggut nyawa lebih dari 800.000 balita setiap tahun, atau sekitar 2.200 setiap hari, termasuk lebih dari 153.000 bayi baru lahir (UNICEF, 2019).

Pada tahun 2016, Indonesia menempati peringkat kesembilan jumlah kematian balita akibat pneumonia terbanyak di dunia, yaitu sebanyak 20.084 balita (IVAC, 2018). Menurut Riskesdas 2018, terjadi peningkatan prevalensi pneumonia pada anak di Indonesia yang sebelumnya 1.6\% pada tahun 2013, meningkat menjadi 2\% (Kementrian Kesehatan RI, 2018).

Pada tahun 2016, jumlah kasus pneumonia pada balita di Kalimantan Timur mencapai 6.908 balita. Jumlah tersebut mengalami peningkatan dibandingkan pada tahun 2013 yang berjumlah 6.683 balita. Kota Balikpapan menduduki peringkat pertama jumlah kasus pneumonia terbanyak di Kaltim, disusul dengan Kota Samarinda yang menduduki peringkat kedua dengan jumlah 1.383 kasus (Dinkes Kaltim, 2017).

Data yang telah diuraikan merupakan masalah yang cukup serius, karena pneumonia merupakan penyakit yang menular lewat udara, dan imunitas balita yang belum matang sehingga penularan infeksi pneumonia pada balita sangatlah mudah. Jika peningkatan kasus pneumonia tidak ditangani dengan baik, maka jumlah kematian balita akibat pneumonia pun juga akan meningkat. Oleh karena itu, pentingnya dilakukan pencegahan sejak dini, yaitu dengan mengetahui faktor-faktor risiko yang dapat meningkatkan kemungkinan seorang balita terinfeksi pneumonia. Ada banyak faktor risiko yang dapat meningkatkan kemungkinan terjadinya pneumonia pada balita, dan yang ditinjau pada penelitian ini adalah usia, berat lahir, dan status gizi. Menurut Depkes RI pada penelitian Rianawati (2014), usia 0-24 bulan lebih rentan terhadap penyakit pneumonia, karena imunitas yang belum sempurna dan saluran pernapasan yang relatif 
sempit (Rianawati \& Kamso, 2014). Pada BBLR, salah satu masalah yang sering terjadi adalah imaturitas imunologis (Damanik, 2014). Menurut Tupasi pada penelitian Widodo (2013), kondisi kurang energi protein (KEP) dapat menyebabkan penurunan imunitas tubuh (Widodo, S.A., \& Hadiana, 2013).

Tujuan penelitian ini adalah untuk mengetahui gambaran karakteristik pasien balita penderita pneumonia di RSUD Abdul Wahab Sjahranie Samarinda berdasarkan faktor risikonya, yaitu usia, berat lahir, dan status gizi.

\section{METODE PENELITIAN}

Penelitian ini merupakan jenis penelitian observasional deskriptif. Penelitian ini dilaksanakan di Instalasi Rekam Medik RSUD Abdul Wahab Sjahranie Samarinda. Populasi penelitian ini adalah seluruh balita penderita pneumonia yang dirawat inap pada periode Januari - Desember 2018. Teknik pengambilan sampel yang digunakan adalah purposive sampling.

Definisi operasional pneumonia adalah penyakit infeksi saluran pernapasan akut yang mengenai parenkim paru yang disebabkan oleh mikroorganisme, yang telah didiagnosis oleh dokter spesialis anak. Usia yang dimaksudkan adalah usia yang menjadi faktor risiko pneumonia, yaitu usia 1-24 bulan, yang dihitung dari tanggal lahir sampai dengan pertama kali masuk rumah sakit. BBLR adalah bayi yang dilahirkan dengan berat lahir <2500 gram tanpa memandang usia kehamilan. Status gizi kurang dinilai berdasarkan penilaian antropometri menggunakan indeks BB/PB atau BB/TB, dengan Zscore $<-2 \mathrm{SD}$.

Data penelitian dianalisis univariat menggunakan tabel distribusi persentase untuk mendeskripsikan variabel penelitian.

\section{HASIL DAN PEMBAHASAN}

Penelitian ini dilaksanakan di Instalasi Rekam Medik RSUD Abdul Wahab Sjahranie Samarinda pada bulan Juli 2019. Sampel yang telah didapatkan, sesuai dengan kriteria inklusi dan eksklusi, berjumlah 42 balita penderita pneumonia.

Tabel 1 Distribusi Frekuensi Karakteristik Pasien Balita Pneumonia.

\begin{tabular}{lcc}
\hline \multicolumn{1}{c}{ Karakteristik Sampel } & Jumlah & Persentase (\%) \\
\hline Jenis Kelamin & & \\
\hline Laki-laki & 29 & 69 \\
\hline Perempuan & 13 & 31 \\
\hline
\end{tabular}




\begin{tabular}{lcc}
\hline Usia (bulan) & 33 & \\
\hline $1-24$ & 9 & 21,6 \\
\hline $25-60$ & & \\
\hline Berat Lahir & 16 & 38,1 \\
\hline BBLR $(<2500 \mathrm{~g})$ & 26 & 61,9 \\
\hline Normal $(\geq 2500 \mathrm{~g})$ & & \\
\hline Status Gizi $(\mathbf{B B} / \mathbf{T B})$ & 24 & 57,1 \\
\hline Gizi Kurang & 18 & 42,9 \\
\hline Gizi Baik & & \\
\hline
\end{tabular}

Berdasarkan Tabel 1, pada penelitian ini didapatkan jumlah kasus pneumonia pada balita berjeniskelamin laki-laki lebih tinggi yaitu 29 balita (69\%) dibandingkan pasien balita perempuan yang berjumlah 13 balita (31\%).

Hasil penelitian ini sejalan dengan penelitian Hartati di Rumah Sakit X di Jakarta (2012) dan Monita (2015) di RSUP DR. M. Djamil Padang, yang menunjukkan bahwa balita penderita pneumonia lebih banyak pada laki-laki dibandingkan pada perempuan, yaitu sebanyak 51,9\% pada penelitian Hartati, dan 55,6\% pada penelitian Monita. Dalam penelitian Hartati disebutkan bawah anak laki-laki adalah faktor risiko yang memengaruhi kesakitan pneumonia karena diameter saluran pernapasan anak laki-laki lebih kecil dibandingkan dengan anak perempuan, atau adanya perbedaan dalam daya tahan tubuh anak laki-laki dan perempuan (Hartati, Nurhaeni, \& Gayatri, 2012; Monita, et al., 2015).

Berdasarkan kelompok usia, jumlah balita pneumonia lebih banyak pada kelompok usia 1-24 bulan, yaitu sebanyak 33 balita $(78,6 \%)$ dibandingkan dengan kelompok usia 25-60 bulan yang hanya berjumlah 9 balita $(21,4 \%)$.

Hasil penelitian ini sejalan dengan penelitian Dalimunthe (2013) di RSUP Adam Malik Medan dan penelitian Wicaksono (2015) di wilayah kerja Puskesmas Gane Luar, Halmahera Selatan, yang menunjukkan bahwa jumlah pasien pneumonia lebih banyak pada kelompok usia $\leq 24$ bulan dibandingkan dengan kelompok usia $>24$ bulan, yaitu sebanyak 78,3\% pada penelitian Dalimunthe, dan $72 \%$ pada penelitian Wicaksono (Dalimunthe, et al., 2013; Wicaksono, 2015). Pada penelitian Dalimunthe (2013) pun dijelaskan bahwa terdapat hubungan yang signifikan atara usia dengan kejadian pneumonia pada balita. Balita dibawah usia 24 bulan 2,563 kali lebih berisiko terinfeksi pneumonia dibandingkan dengan balita berusia diatas 24 bulan (Dalimunthe, et al., 2013).

Hasil penelitian ini sesuai dengan teori yang menyebutkan bahwa usia 0-24 bulan merupakan merupakan faktor risiko terjadinya pneumonia pada balita, karena imunitas 
yang belum sempurna dan saluran pernapasan yang relatif sempit (Rianawati \& Kamso, 2014). Usia merupakan faktor biologis pejamu atau host yang dapat memengaruhi terjadinya penyakit (Nugrahaeni, 2014). Bayi dan balita merupakan kelompok usia yang rawan terhadap penyakit infeksi karena memiliki imunitas yang masih rendah dibandingkan dengan orang dewasa (Hartati, et al., 2012).

Berdasarkan penjelasan di atas, dalam upaya menurunkan angka kejadian pneumonia pada balita, hendaknya lebih difokuskan kepada kelompok usia 2 tahun ke bawah.

Berdasarkan pengelompokan, berat lahir normal jika $\geq 2500$ gram dan BBLR jika $<2500$ gram. Pada Tabel 1, terlihat bahwa pasien pneumonia lebih banyak memiliki berat lahir normal yaitu 26 balita $(61,9 \%)$, dibandingkan dengan balita yang memiliki riwayat BBLR, yaitu sebanyak 16 balita atau 38,1\%. Hasil penelitian ini sejalan dengan penelitian Mairi (2015) dan Hadisuwarno (2015) yang menunjukkan bahwa jumlah pasien pneumonia lebih banyak memiliki berat lahir normal dibandingkan BBLR, yaitu sebanyak $91,1 \%$ pada penelitian Mairi, dan $84,7 \%$ pada penelitian Hadisuwarno (Hadisuwarno, et al., 2015; Mairi, et al., 2015).

Hasil penelitian ini tidak sesuai dengan teori yang menyebutkan bahwa BBLR merupakan faktor risiko kejadian pneumonia pada balita (Said, 2015). Salah satu masalah yang sering terjadi pada BBLR yaitu imaturitas imunologis, sehingga BBLR mempunyai kecenderungan ke arah peningkatan terjadinya infeksi, termasuk infeksi saluran pernapasan yang salah satunya adalah pneumonia (Kementrian Kesehatan RI, 2015; Said, 2015).

Perbedaan hasil penelitian dengan teori menunjukkan bahwa penanganan BBLR saat ini sudah baik. Selain itu, bukan hanya BBLR yang merupakan faktor risiko pneumonia, sehingga, risiko pneumonia pada BBLR dapat diturunkan dengan mencegah dan/atau memperbaiki faktor risiko pneumonia lainnya.

Berdasarkan indeks berat badan menurut panjang badan atau tinggi badan, diperoleh jumlah pasien pneumonia lebih banyak memiliki status gizi kurang, yaitu 24 balita $(57,1 \%)$, dibandingkan dengan balita dengan status gizi baik yang jumlahnya 18 balita (42,9\%). Hasil penelitian ini sejalan dengan penelitian Monita (2015) di RSUP DR. M. Djamil Padang, dan penelitian Lestari (2017) di RSUD Dr. Moewardi Surakarta, yang menunjukkan bahwa jumlah pasien pneumonia lebih banyak memiliki status gizi kurang dibandingkan dengan status gizi baik, yaitu sebanyak $62 \%$ pada penelitian Monita, dan 57,1\% pada penelitian (Lestari, et al., 2017; Monita, et al., 2015). Pada 
penelitian Rasyid (2013) pun dijelaskan bahwa terdapat hubungan yang signifikan atara status gizi dengan kejadian pneumonia pada balita. Balita berstatus gizi kurang 2,334 kali lebih berisiko terinfeksi pneumonia dibandingkan dengan balita berstatus gizi baik (Rasyid, 2013).

Hasil penelitian ini sesuai dengan teori yang menyatakan bahwa gizi kurang merupakan faktor risiko pneumonia pada balita (Said, 2015). Gizi yang memadai sangat penting pada anak usia dini untuk memastikan pertumbuhan yang sehat dan sistem kekebalan yang kuat (UNICEF, WHO, The World Bank, 2012). Menurut Tupasi (2000) dalam penelitian Widodo (2013) kondisi kurang energi protein (KEP) dapat menyebabkan penurunan imunitas tubuh sehingga mengakibatkan terjadinya infeksi, yang salah satunya adalah pneumonia (Widodo, et al., 2013).

Berdasarkan penjelasan di atas, dalam upaya menurunkan angka kejadian pneumonia pada balita, gizi kurang sebagai faktor risiko pneumonia dapat dicegah mulai dari masa kehamilan, yaitu dengan mengonsumsi makanan yang sehat bagi ibu hamil. Selain itu, faktor status gizi juga erat kaitannya dengan faktor ASI eksklusif. Pemberian ASI secara ekslusif selama 6 bulan baik untuk memperbaiki status gizi, sehingga risiko terjadinya pneumonia pada balita dapat diturunkan.

\section{SIMPULAN}

Simpulan yang didapatkan pada penelitian yang dilakukan di RSUD Abdul Wahab Sjahranie Samarinda adalah sebagai berikut.

1. Pneumonia balita lebih banyak ditemukan pada kelompok usia 1-24 bulan $(78,6 \%)$ dibandingkan dengan kelompok usia 25-60 bulan $(21,4 \%)$.

2. Pneumonia balita lebih banyak ditemukan pada balita dengan berat lahir normal $(61,9 \%)$ dibandingkan dengan balita dengan riwayat BBLR $(38,1 \%)$.

3. Pneumonia balita lebih banyak ditemukan pada balita dengan gizi kurang $(57,1 \%)$ dibandingkan dengan gizi baik $(42,9 \%)$.

\section{DAFTAR PUSTAKA}

Dalimunthe, W., Daulay, R., \& Daulay, R. (2013). Significant Clinical Features in Pediatric Pneumonia. Paediatrica Indonesiana, 37-41. doi:https://doi.org/10.14238/pi53.1.2013.37-41

Damanik, S. (2014). Klasifikasi Bayi Menurut Berat Lahir dan Masa Gestasi. In M. Kosim, A. Yunanto, R. Dewi, G. Sarosa, \& A. Usman, Buku Ajar Neonatologi (pp. 11-30). Jakarta: Ikatan Dokter Anak Indonesia. 
Jurnal Kebidanan Mutiara Mahakam, Vol 8, No 1, Tahun 2020, Hal 38-45

Dinkes Kaltim. (2017). Profil Kesehatan 2016. Samarinda: Dinas Kesehatan Provinsi Kalimantan Timur. Retrieved January 2019, from https://www.depkes.go.id/resources/download/profil/PROFIL KES PROVINSI 2016/23_Kaltim_2016.pdf

Hadisuwarno, W., Setyoningrum, R. A., \& Umiastuti, P. (2015). Host Factors Related to Pneumonia in Children Under 5 Years of Age. Paediatrica Indonesiana, 248-251. doi:https://doi.org/10.14238/pi55.5.2015.248-51

Hartati, S., Nurhaeni, N., \& Gayatri, D. (2012, Maret). Faktor Risiko Terjadinya Pneumonia pada Anak Balita. Jurnal Keperawatan Indonesia, 15, 13-20. doi:10.7454/jki.v15i1.42

IVAC. (2018). Pneumonia \& Diarrhea Progress Report 2018. -: International Vaccine Access Center; John Hopkins Bloomberg School of Public Health. Retrieved February 1, 2019, from https://stoppneumonia.org/wpcontent/uploads/2018/11/Pneumonia-and-Diarrhea-Progress-Report-2018.pdf

Kementrian Kesehatan RI. (2015). Profil Kesehatan Indonesia 2014. Jakarta: Kementrian Kesehatan RI. Retrieved from http://www.depkes.go.id/resources/download/pusdatin/profil-kesehatanindonesia/profil-kesehatan-indonesia-2014.pdf

Kementrian Kesehatan RI. (2018, November 2). Potret Sehat Indonesia dari Riskesdas 2018. Potret Sehat Indonesia dari Riskesdas 2018, p. . Retrieved January 2019, from depkes.go.id/article/view/18110200003/potret-sehat-indonesia-daririskesdas-2018.html

Lestari, N., Salimo, H., \& Suradi. (2017). Role of Biopsychosocial Factors on The Risk of Pneumonia in Children Under-Five Years Old at Dr. Moewardi Hospital, Surakarta. Jornal of Maternal and Child Health, 162-175. doi:https://doi.org/10.26911/thejmch.2017.02.02.07

Mairi, M., Dani, \& Widyarto, B. (2015). Gambaran Karakteristik Balita Penderita Pneumonia di Rumah Sakit Immanuel Bandung Tahun 2013. Maranatha Repository System, 1-7. Retrieved October 2019, from https://repository.maranatha.edu/12596/

Monita, O., Yani, F. F., \& Lestari, Y. (2015). Profil Pasien Pneumonia Komunitas di Bagian Anak RSUP DR. M. Djamil Padang Sumatera Barat. Jurnal Kesehatan Andalas, 218-226. doi:https://doi.org/10.25077/jka.v4.i1.p\%25p.2015

Noorbaya, S., Sorta Llyod, S. and Eka Putri, Y. (2019) "Faktor-Faktor Yang Mempengaruhi Rendahnya Cakupan Asi Eksklusif Pada Bayi Umur 0-6 Bulan Di Bidan Praktik Salasiah Gun Kecamatan Palaran Samarinda Tahun 2017”, Jurnal Kebidanan Mutiara Mahakam, 5(2), pp. 68-72. Available at: http://jurnal.stikesmm.ac.id/index.php/jkmm/article/view/19 (Accessed: 3March2020).

Nugrahaeni, D. K. (2014). Konsep Dasar Epidemiologi. Jakarta: EGC. 
Jurnal Kebidanan Mutiara Mahakam, Vol 8, No 1, Tahun 2020, Hal 38-45

Rasyid, Z., 2013. Faktor-Faktor yang Berhubungan dengan Kejadian Pneumonia Anak Balita di RSUD Bangkinang Kabupaten Kampar. Jurnal Kesehatan Komunitas, Volume 2, pp. 136-140.

Rianawati, D. A., \& Kamso, S. (2014). Faktor-Faktor yang Berhubungan dengan Kejadian Pneumonia pada Balita di Puskesmas Kecamatan Pancoran Jakarta Selatan Tahun 2014. -, 1-18. Retrieved February 2019, from http://lib.ui.ac.id/naskahringkas/2016-06/S55954-Diah\%20Ayu\%20Rianawati

Said, M. P. (2015). Pneumonia. In I. D. Indonesia, N. Rahajoe, B. Supriyatno, \& D. Setyanto (Eds.), Buku Ajar Respirologi Anak (1 ed., pp. 350-365). Jakarta: Badan Penerbit Ikatan Dokter Anak Indonesia.

UNICEF, WHO, The World Bank. (2012). Levels \& Trends in Child Malnutrition. New York; Geneva; Washington, DC: UNICEF, WHO, The World Bank. Retrieved March 2019, from https://www.semanticscholar.org/paper/Levels-and-trends-inchild-malnutrition.-World-Bank-deOnisBrown/ef7e6e7ec7d5087ffc268d386f7559962347955b

UNICEF. (2019, November .). A Child Dies of Pneumonia Every 39 Seconds. Pneumonia, p. 1. Retrieved November 2019, from https://data.unicef.org/topic/child-health/pneumonia/

WHO. (2019, August 2). Pneumonia. Pneumonia, p. 1. Retrieved September 2019, from https://www.who.int/news-room/fact-sheets/detail/pneumonia

Wicaksono, H. (2015, October-December). Nutritional Status Affects Incidence of Pneumonia in Underfives. Folia Medica Indonesiana, 51(4), 285-291. doi:http://dx.doi.org/10.20473/fmi.v51i4.2861

Widodo, P., S.A., G., \& Hadiana, S. Y. (2013). Hubungan Status Gizi Terhadap Terjadinya Infeksi Saluran Pernapasan Akut (ISPA) pada Balita di Puskesmas Pajang Surabaya. Skripsi thesis, Universitas Muhammadiyah Surakarta, 1-13. Retrieved March 2019, from http://eprints.ums.ac.id/id/eprint/22566 